\title{
KONTRIBUSI KEPEMIMPINAN KEPALA SEKOLAH: Profesionalisasi Guru dan Iklim Sekolah terhadap Motivasi Kerja Guru di MTsN Pasir Lawas Kabupaten Tanah Datar \\ Enwin \\ Guru MTSN Pasir Lawas, \\ Koresponden: Penumahan Arai Pinang I Blok I No.2 Kuburajo Lima Kaum Kabupaten Tanah Datar
}

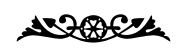

\begin{abstract}
Contribution Leadership of Head Scholl: Professionalization of Teachers and School Climate to Teacher Work Motivation in MTsN Pasir Lawas Tanah Datar. Based on observations in the field, was impressed that the junior secondary school teachers' motivation Affairs (MTsN) Pasir Lawas Tanah Datar low, it is influenced by the leadership of the principal, teacher professionalization and school climate. If the condition is left is feared will affect efforts to improve the quality of education State in junior secondary school (MTsN) Pasir Lawas Tanah Datar. This study aims to reveal how much the contribution of principal leadership, teacher professionalization and school climate Against junior secondary school teachers' job motivation Affairs (MTsN) Pasir Lawas Tanah Datar. The hypothesis tested in this study were: (1) the principal's leadership contributed Against motivation of teachers (2) Against the Professionalization of teachers' motivation to contribute to the work of teachers (3) school climate contribute Against motivation of teachers (4) principal leadership, teacher professionalization, and school climate contribute Against teacher motivation.
\end{abstract}

Kata Kunci: Kepemimpinan, profesionalisasi, motivasi kerja

\section{PENDAHULUAN}

Perkembangan ilmu pengetahuan dan teknologi telah membawa perubahan hampir di semua aspek kehidupan manusia dimana perubahan tersebut telah membawa manusia ke dalam era persaingan global yang semakin ketat. Untuk mampu berperan dalam persaingan global, maka sebagai bangsa perlu terus berupaya meningkatkan mutu pendidikan karena kualitas sumber daya manusia ditentukan oleh pendidikan yang berkualitas, pendidikan berkualitas hanya akan muncul dari sekolah yang berkualitas.

Undang-undang RI no 20 tahun 2003 tentang sistem pendidikan nasional, UU RI nomor 14 tahun 2005 tentang guru dan dosen dengan jelas dinyatakan bahwa guru adalah pendidik profesional. Sebagai agen pembelajaran guru harus memiliki kompetensi yang meliputi kompetensi pedagogik, kepribadian, sosial, dan profesional, dengan tugas utama mendidik, 
mengajar, membimbing, mengarahkan, melatih, menilai, dan mengevaluasi peserta didik.

Mendidik berarti meneruskan dan mengembangkan nilai-nilai dalam kehidupan dan melakukan pembinaan akhlak yang mulia. Guru sebagai pendidik hendaklah mempunyai citra yang baik di mata anak didik dan masyarakat sehingga layak menjadi panutan dan teladan. Masyarakat selalu melihat bagaimana sikap dan perbuatan guru sehari-hari, bagaimana guru memberikan layanan dan memberi dorongan kepada anak didiknya, bahkan sampai memperhatikan bagaimana guru berpakaian, berbicara, bergaul dengan murid, sesama guru dan masyarakat. Oleh karena itu hendaknya guru menyadari bahwa tugas yang diembannya tidaklah ringan.

Mengajar berarti meneruskan dan mengembangkan keterampilan-keterampilan siswa. Menilai dan mengevaluasi berarti memberi gambaran sejauh mana penguasaan siswa. Selain itu dalam bentuk pengabdian, guru mempunyai tugas dalam bidang kemanusiaan dan kemasyarakatan yaitu menjadikan dirinya sebagai orang tua kedua. Dalam hal ini guru hendaknya mampu menarik simpati muridnya, sehingga ia menjadi idola dan pendorong siswa.

Dari hal-hal yang dikemukakan di atas, jelas bahwa hal mendasar yang mampu menopang suatu keberhasilan pendidikan yaitu membangun masa depan generasi bangsa dengan guru yang mempunyai visi ke depan, meningkatkan mutu pendidikan dengan guru yang unggul, mencetak prestasi dengan guru yang mempunyai motivasi berprestasi, menciptakan jiwa yang ulet dengan guru yang mampu mengubah hambatan menjadi peluang dan mempunyai daya juang yang tinggi, menciptakan terobosan baru dengan guru yang kritis, inofatif dan kreatif.

Sebagian guru sudah melaksanakan tugas dan fungsinya dengan maksimal sebagai pendidik profesional, di samping mengajar dia juga mendidik, membimbing, mengarahkan, melatih, menilai, dan mengevaluasi peserta didik dengan penuh ikhlas. Akan tetapi masih dijumpai guru yang melaksanakan tugasnya asal jadi. Hal ini tentunya berpengaruh terhadap kualitas hasil pendidikan secara makro, fenomina ini masih terdapat di hampir semua sekolah.

Dalam melaksanakan pembelajaran, metode yang digunakan belum bervariasi, mengajar tanpa media dan alat bantu pembelajaran, metoda penyampaian tidak relefan dengan indikator yang harus dikuasai siswa, fokus pembelajaran hanya pada anak yang cepat sementara anak yang lambat terabaikan, memberikan tugas apa yang ada dalam buku, serta belum melakukan penilaian yang terencana, transparan dan menindak lanjuti hasil penilaian, hal ini mengakibatkan daya serap siswa rendah dan hasil belajarnya tidak sesuai dengan kriteria ketuntasan minimal (KKM) yang ditetapkan oleh guru. 
Kemudian dari hasil perbincangan penulis dengan beberapa orang guru, terungkap bahwa keengganan guru terhadap tugas disebabkan karena terlalu banyak beban administrasi, model perangkat pembelajaran yang sering berubah-ubah, dan guru belum mampu menerima pembaharuan, meskipun berbagai pelatihan telah mereka ikuti, tetapi hasilnya seperti tidak membawa implikasi yang berarti bagi berkembangnya kualitas profesional guru.

Perhatikan misalnya, jika seorang guru telah kembali ke sekolah namun jarang yang berusaha mengembangkan atau paling tidak mengimplementasikan ilmu yang diperoleh dari pelatihan. Mungkin masih lumayan jika guru mengikuti kegiatan pelatihan secara penuh. Yang disayangkan, dan ini umum terjadi, guru mengikuti pelatihan hanya sekedar untuk mendapatkan sertifikat untuk syarat sertifikasi. Jika hanya mencari sertifikat yang mendorong guru untuk mengikuti pelatihan maka dapat dibayangkan begitu rendahnya tanggung jawab dan kualitas profesional seorang guru.

Halyangsamajuga terjadi padakompetensi kepribadian yang menyangkut seljati diri sebagai pribadi yang baik, bertanggung jawab serta selalu mengembangkan diri, sering diabaikan seorang guru, mereka tidak berusaha menambah wawasan dalam rangka pengembangan profesionalitasnya, mereka tidak sadar bahwa ilmu dan teknologi dibidang pendidikan terus berubah dan berkembang, mereka seakan tidak memahami bahwa tanpa belajar, seorang guru akan ketinggalan zaman bahkan akan ketinggalan oleh siswanya.

Hal lain yang teramati, masih dijumpai guru yang suka marah-marah menghardik, mencela dan memperlakukan siswanya seperti orang dewasa yang kecil tanpa memperhatikan faktor-faktor psikologis dan ilmu jiwa anak. Guru menjadi segalagalanya dalam proses pembelajaran, yang harus dipatuhi dan dituruti. Guru belum lagi sebagai pelayan yang membuat siswa belajar, tetapi sebagai pusat belajar dan pusat informasi yang harus didengar. Tampaknya guru kurang menyukai tugas dan jabatan yang diembannya.

Begitu pula berkomunikasi dengan teman sejawat dan pimpinan, masih ada guru bernada sisis dan kurang simpatik. Apalagi yang bersangkut dengan tugas, tidak suka dikritik dan enggan menerima pembaharuan, senang berkumpul pada ruangan tertentu, membicarakan hal-hal yang tidak berhubungan dengan peningkatan profesinya, lebih suka membicarakan issu ketimbang membicarakan masalah sekolah. Hanya sebahagain kecil diantara guru-guru yang menggunakan waktu senggangnya untuk belajar, mengoreksi pekerjaan siswa, membicarakan kemajuan dan masalah yang dihadapi siswa dalam proses belajar mengajar.

Berdasarkan fenomena yang dikemukakan di atas dapat disimpulkan bahwa unjuk kerja guru memperhatikan 
pola sikap, prilaku, pola pikir dan budaya kerja yang menjauhi karakteristik seorang pendidik profesional. Dengan kata lain unjuk kerja guru kurang profesional, wibawa dan citra guru belum sesuai dengan harapan seakan-akan telah terjadi degradasi pada profesi guru. Telah terjadi kemerosotan pola pikir, pola tingkah laku, dan pola pikir guru terhadap tugasnya. Saat in sedikit sekali guru yang menjadi idola bagi siswanya, kata-katanya jarang lagi didengar, perintahnya jarang dituruti, rasa enggan dan mendongkol terhadap guru kelihatan dari sikap siswa seperti : merasa terpaksa untuk belajar, mereka mengabaikan nasehat guru, suka bergurau mengganggu teman, bahkan ada ayng memberikan lebel tertentu dan mencemoohkan guru yang sedang berjalan di hadapan mereka.

Tugas dan peran guru sangat penting dalam dunia pendidikan yang tidak dapat digantikan oleh teknologi apapun. Namun pada kenyataannya masih ada guru-guru sekolah yang belum komitmen dengan peranannya yang penting itu sebagaimana yang dikemukakan diatas. Jika fenomena ini dibiarkan tentunya akan berpengaruh terhadap kualitas pendidikan dan masa depan bangsa. Dikatakan oleh uzer usman "citra guru mencerminkan masa depan bangsa."

Apa yang menyebabkan prilaku guru seperti itu? dari gambaran dan fenomena, secara umum disimpulkan karena rendahnya motivasi kerja guru. Untuk itu penulis memandang perlu untuk melakukan penelitian, mencari pemicu rendahnya motivasi kerja guru tersebut, serta melakukan pengkajian terhadap faktor-faktor yang mungkin mempengaruhinya, khususnya di MTsN Pasir Lawas Kabupaten Tanah Datar.

Metode penelitian yang digunakan dalam penelitian ini adalah penelitian kuantitatif dengan jenis penelitian korelasional. Penelitian korelasional bertujuan untuk melihat apa yang telah terjadi. Pendekatan analisisnya adalah analisis deskriktif kuantitatif yaitu menggambarkan apa adanya tentang suatu variabel melalui angka-angka. Jenis statistik yang dipakai adalah inferiansial yaitu menggeneralisasikan hasil penelitian yang ada pada sampel bagi populasi.

Dengan pendekatan regresional akan diungkapkan hubungan kepemimpinan kepala sekolah terhadap motivasi kerja guru, hubungan propesionalisai guru terhadap motivasi kerja guru, dan kontribusi iklim sekolah terhadap motivasi kerja guru. Dan kentribusi kepemimpinan kepala sekolah dan iklim sekolah terhadap motivasi kerjs guru, kontribusi propesionalisasi dan iklim sekolah secara bersama-sama terhadap motivasi kerja guru, serta kontribusi kepemimpinan kepala sekolah, profesionalisasi dan iklim sekolah secara bersama-sama terhadap motivasi kerja guru.

Definisi operasional adalah definisi yang didasarkan atas sifat-sifat hal yang 
terdefinisikan, diamati atau diobservasi. Variabel dalam penelitian ini adalah :

\section{a. Kepemimpinan kepala sekolah (X1)}

Kepemimpinan kepala sekolah yang dimaksud dalam penelitian ini adalah sikap dan perilaku dalam mempengaruhi, menggerakkan, dan mengarahkan guru untuk melaksanakn tugas sebagai pendidik, pengajar dan pembimbing, mengarahkan, melatih, menilai dan mengevaluasi peserta didik. Adapun indikator kepemimpinan kepala sekolah adalah : a) mendorong guru, b) mengarahkan guru, c) membimbing guru, d) memfasilitasi kegiatan, e) memberikan tauladan.

\section{b. Profesionalisasi guru (X2)}

Profesionalisasi guru adalah upaya proses pembinaan dan pengembangan kemampuan guru agar menjadi guru yang kompeten dalam tugasnya. Adapun yang menjadi indikatornya adalah : a) pembelajaran diri, b) kegiatan tutorial, c) bantuan kepala sekolah dan pengawas, d) fasilitas MGMP, dan e) kesempatan melanjutkan pendidikan.

\section{c. Iklim sekolah (X3)}

Iklim sekolah adalah suasana sekolaha untuk mendukung terselenggaranya kegiatan belajar mengajar yang didukung adanya hubungan antar pribadi diantara penghuninya. Indikator dari iklim sekolah adalah : a) keterbukaan, b) keakraban, c) saling menghargai, d) saling mendukung, e) mendahulukan kepentingan bersama.

\section{d. Motivasi kerja guru (Y)}

Motivasi kerja guru adalah kekuatan, daya dorong yang dimiliki oleh guru yang berupa semangat, kesungguhan, rasa tanggung jawab dan kesukaan guru terhadap tugasnya. Indikator dari motivasi kerja adalah : a) kesungguhan, b) menyukai pekerjaan, c) Tanggung jawab, d) semangat, dan e) komitmen.

Instrumen yang digunakan dalam penelitian ini ditentukan berdasarkan beberapa hal, yaitu instrumen dengan inspirasi pada latar belakang masalah dan landasan teori, kesesuaian instrumen dengan tempat penelitian, dan kesesuaian dengan indikator setiap variabel. Berdasarkan hal yang demikian, instrumen penelitian yang digunakan dalam penelitian ini dirancang dan dikembangkan sendiri oleh peneliti dan mengembangkan instrumen-instrumen peneliti yang relevan.

Penyusunan kuesioner dilakukan dengan langkah-langkah: 1) pembuatan kisi-kisi instrumen, 2) menyusun butirbutir pernyataan berdasarkan indikator, 3) melakukan diskusi dan konsultasi dengan para pembimbing dan melakukan uji coba untuk mendapatkan validasi dan reliabilitas intrumen yang disusun.Agar responden mudah memahami butirbutir pernyataan dalam kuisioner maka dalam penyusunan memperhatikan 
kemudahan pengisian, yaitu dengan cara menghindari pernyataan yang akan membingungkan, kata-kata abstrak, dan kata-kata yang menimbulkan antipati.

\section{PEMBAHASAN}

Berdasarkan hasil analisis data dan tingkat pencapaian responden setiap variabel ukur dapat diterangkan bahwa tingkat pencapaian Kepemimpinan kepala sekolah, Profesionalisasi guru dan Iklim sekolah berada pada kategori sedang/ cukup, sedangkan motivasi kerja guru berada pada kategori rendah/kurang. Temuan ini ternyata menguatkan dugaan awal peneliti dari hasil pre-survei, yang mengindikasikan rendahnya motivasi kerja guru. Sedangkan kepemimpinan kepala sekolah dan upaya profesionalisasi guru serta iklim sekolah, semula diperkirakan rendah ternyata ditemukan sudah termasuk kategori sedang/cukup. Hal ini dimungkinkan oleh pengamatan awal yang dilakukan secara singkat dan kurang sistematis, serta dengan menggunakan pengamatan indera. Karena aspek yang dicermati adalah aspek psikologis dan bersifat internal atau dalam diri guru. Maka pengamatan awal tanpa instrument yang standar belum mampu mengungkap hakikat sebenarnya, sementara penelitian ini dilakukan dengan sistematis, prosedural dan menggunakan alat ukur yang standar serta alat analisis yang baku, maka hasil penelitian lebih dapat dipercaya.
Temuan yang berkaitan dengan pengujian hipotesis penelitian menunjukkan kontribusi masing-masing Kepemimpinan kepala sekolah terhadap motivasi kerja guru $16,3 \%$, Profesionalisasi guru terhadap motivasi kerja guru $8 \%$, Iklim sekolah terhadap motivasi kerja guru $8,5 \%$, sementara kontribusi bersama ketiga variabel adalah 24,8\%, hal ini menunjukan bahwa variabel kepemimpinan kepala sekolah, Profesionalisasi guru dan Iklim sekolah secara bersama-sama terhadap motivasi kerja guru $24,8 \%$, terhadap variabel motivasi kerja guru, sedangkan 75,2 lagi berasal dari faktor lain yang tidak dikaji dalam penelitian ini.

Secara khusus, temuan ini menegaskan bahwa untuk meningkatkan motivasi kerja guru hanya mungkin optimal bila factor kepemimpinan kepala sekolah ditingkatkan beriringan dengan pembinaan profesionalisme guru, dan disinergikan penciptaan lingkungan sekolah dan iklim sekolah yang menciptakan situasi kerja yang produktif serta pendekatan persuasive dan edukatif dalam penerapan manajemen sekolah.

Lebih lanjut dapat dijelaskan dari rangkuman tabel variabel-variabel penelitian $\mathrm{X}_{1}, \mathrm{X}_{2}$, dan $\mathrm{X}_{3}$ terhadap variabel terikat Y, baik secara sendiri-sendiri maupun secara bersama-sama berkontribusi positif terhadap motivsi kerja guru di MTsN Pasir Lawas. Temuan ini mendukung teori motivasi kelompok yang dikemukakan oleh David McCleland yang mengatakan 
bahwa kebutuhan motivasi utama dalam diri manusia yang berkaitan dengan situasi kerja need for achievement, need for power, dan need for affiliation ternyata ditemukan dalam penelitian ini. Setiap orang bermotivasi untuk mengembangkan diri, menerima dan member pengaruh, dan berhubungan dekat yang mutual.

Selanjutnya teori expectancy juga mendukung temuan penelitian ini yang mengatakan bahwa ada keterkaitan antara kinerja dengan usaha, seseirang termotivasi untuk berusaha karena harapan untuk sukses dan adanya peluang untuk mendapai sukses guna memperoleh keberhasilan. Didukung lagi dengan teori motivasi kerja yang dikemukakan oleh McGregor bahwa hubungan kelompok yang kohesif merupakan pendekatan untuk memaksinalkan kinerja, dan orang akan melakukan pengarahan diri dan mengendalikan diri jika memiliki komitmen terhadap tugasnya.

Dapat disimpulkan bahwa temuan penelitian ini mendukung temuan penelitian sebelumnya dan didukung oleh teori-teori motivasi dalam menciptakan motivasi kerja. berdasarkan rangkuman tabel dapat dijelaskan bahwa ketiga variabel bebas mempunyai korelasi yang berbeda terhadap motivasi kerja guru. Korelasi yang paling besar adalah kepemimpinan kepala sekolah, kemuadian variabel profesionalisasi guru dan iklim sekolah. Dengan diperoleh besaran hubungan variabel $(\mathrm{X})$ dengan variabel terikat (Y) maka dapat pula dijelaskan besarnya dampak yang diberikan oleh variabel bebas terhadap variabel terikat. Kontribusi yang paling besar adalah kepemimpinan kepala sekolah dari 16\% dan dan sangat signifikan. Selanjutnya kontribusi positif dari profesionalisasi guru sebesar $8 \%$ yang signifikan. Kontribusi positif dari setiap variabel bebas terhadap 8,5\% yang signifikan. Kontribusi positif dari variabel bebas terhadap motivasi kerja guru juga dapat diprediksi dengan angka koefesien arah garis regresinya sebesar 0,65 skala dari kepemimpinan kepala sekolah, 0,157 skala dari profesionalisasi guru dan 0,68 skala dari variabel hubungan inter personal.

Hasil analisis data dan rangkuman hipotesis menunjukkan bahwa keempat hipotesis teruji secara empiris. Dengan demikian diyakini bahwa Kepemimpinan kepala sekolah berkontribusi terhadap motivasi kerja guru, Profesionalisasi guru, terhadap motivasi kerja guru, Iklim sekolah terhadap motivasi kerja guru, Kepemimpinan kepala sekolah, Profesionalisasi guru dan Iklim sekolah secara bersama-sama terhadap motivasi kerja guru. Maka sesuai dengan tujuan penelitian dapat diinformasikan bahwa :

1. Kontribusi kepemimpinan kepala sekolah terhadap motivasi kerja guru di MTsN Pasir Lawas memberikan kontribusi yang terbesar terhadap sikap motivasi kerja guru. Hasil penelitian ini didukung oleh apa yang dikatakan oleh Aziz Wahab (2006:39) yang mengatakan bahwa motivasi kerja 
guru, namun bila dilihat dari kontribusi masing-masing prediktor terhadap motivasi kerja guru sikap dan tanggung jawab profesional serta komitmen guru terhadap tugas-tugasnya akan ditentukan oleh iklim kerja yang diciptakan oleh kepala sekolah melalui prilaku dan gaya kepemimpinannya sebagai kepala sekolah. Kemudian dijelaskan oleh Sahertian (1990:78) kepemimpinan kepala sekolah yang kondusif dapat meningkatkan motivasi kerja guru, sehingga ia mampu melaksanakan tugasnya dengan sungguhsungguh dan penuh rasa tanggung jawab. Dengan demikian untuk meningkatkan motivasi kerja guru dapat dilakukan melalui kepemimpinan kepala sekolah, yang efektif dengan hubungan manusiawi yang harmonis serta membina dan mengembangkan kerja sama untuk saling menerima dan memberi informasi akan berdampak pada mitivasi kerja guru.

2. Kontribusi profesionalisme guru terhadap motivasi kerja guru di MTsN Pasir Lawas. Profesionalisasi guru merupakan variabel bebas yang juga berkontribusi positif terhadap motivasi kerja guru, dapat diprediksi memberikan pengaruh terhadap motivasi kerja dengan koefesien arahnya 0,157 skala. Maknanya bahwa dalam hasil penelitian ini Profesionalisasi guru penting dilakukan untuk meningkatkan motivasi kerja guru. Profesionalisasi yang dilakukan, apakah melalui pembelajaran diri maupun dengan bantuan teman sejawat, kepala sekolah, dan pengawas pada dasarnya adalah untuk meningkatkan kompetensi guru agar menjadi guru yang profesional. Mendukung pendapat soetjipto (1999:60) bahwa seorang yang menguasai tentang suatu pekerjaan akan mempunyai motivasi yang besar untuk melakukannya.

3. Kontribusi iklim sekolah terhadap motivasi kerja guru di MTsN Pasir Lawas, Iklim sekolah juga berkontribusi signifikan terhadap motivasi kerja guru sebesar 8,5\%, ternyata iklim sekolah memberikan kontribusi sedikit lebih besar, tetapi angka koefesien arahnya lebih besar yaitu 0,68. Dengan demikian iklim sekolah besar pengaruhnya terhadap motivasi kerja guru. Temuan ini mendukung penelitian yang dilakukan oleh Saelan Hasri (2002:97) bahwa iklim sekolah memberikan kontribusi terhadap prestasi kerja guru, dengan demikian diyakini apabila iklim sekolah baik ditandai dengan membangun keterbukaan, keakraban,saling menghargai, saling mendukung dan mendahulukan kepentingan bersama maka motivasi kerja guru akan meningkat.

4. Kontribusi kepemimpinan kepala sekolah, profesionalisasi guru dan iklim sekolah secara bersama-sama terhadap motivasi kerja guru di MTsN Pasir Lawas, bila dibandingkan besaranya kontribusi masing-masing variabel secara 
sendiri-sendiri maka kontribusi yang diberikan oleh variabel secara bersamasama lebih besar, dari hasil penelitian ditemukan kontribusi kepemimpinan kepala sekolah terhadap motivasi kerja guru 16,3\%, Profesionalisasi guru terhadap motivasi kerja guru $8 \%$, Iklim sekolah terhadap motivasi kerja guru $8,5 \%$, selanjutnya bila kita lihat dari hasil penelitian, ternyat kepemimpinan kepala sekolah, Profesionalisasi guru dan Iklim sekolah secara bersama-sama terhadap motivasi kerja guru 24,8\%.

Dari hasil temuan yang tertera diatas ternyata kontribusi yang diberikan variabel secara berpasangan lebih besar dari kontribusi secara sendiri-sendiri. Artinya untuk meningkatkan motivasi kerja guru maka diperlukan kepemimpinan kepala sekolah, Profesionalisasi guru dan Iklim sekolah yang kondusif. Dalam kontek manajemen, kepemimpinan kepala sekolah yang baik adalah pimpinan yang berusaha menjadikan guru profesional dan menciptakan iklim sekolah yang kondusif sehingga motivasi kerja guru dapat ditingkatkan dan prestasi kerja akan lebih baik dari kondisi sebelumnya.

Berdasarkan analisis korelasi berganda dan parsial diperoleh kontribusi murni masing masing variabel terhadap sikap motivasi kerja guru sebagai berikut :

a. kontribusi kepemimpinan kepala sekolah terhadap motivasi kerja guru 12,8\%, b. kontribusi Profesionalisasi guru terhadap motivasi kerja guru 5,5\%,

c. kontribusi Iklim sekolah terhadap motivasi kerja guru 6,5\%,

d. kontribusi kepemimpinan kepala sekolah, Profesionalisasi guru dan Iklim sekolah secara bersama-sama terhadap motivasi kerja guru $24,8 \%$, dengan kontaminasi bersa $1 \%$ dianggap kecil dan dapat diabaikan, maka kontribusi murni secara bersama kepemimpinan kepala sekolah, Profesionalisasi guru, Iklim sekolah terhadap motivasi kerja guru $24,8 \%$, sisanya sebesar $75,2 \%$ adalah kontribusi dari faktor lain yang belum terungkap dalam penelitian ini.

Berdasarkan hasil uji statistik dari masing-masing uji hipotesis, berkontribusi masing-masing variabel bebas dapat diprediksi dengan persamaan regresi sebagai berikut :

1. Untuk hipotesis pertama $Y=54,79+0,55$ $\mathrm{X}_{1}$, artinya bila kepemimpinan kepala sekolah dikembangkan satu skala maka motivasi kerja guru MTsN Pasir Lawas akan bertambah sebesar 0,55 skala.

2. Untuk hipotesis kedua $Y=81,28+0,388$ $\mathrm{X}_{2}$, artinya bila profesionalisasi guru dikembangkan satu skala maka motivasi kerja guru MTsN Pasir Lawas akan bertambah sebesar 0,388 skala. Persamaan ini memberikan makna pada variabel profesionalisasi guru berpengaruh pada peningkatan motivasi kerja guru MTsN Pasir Lawas. 
3. Untuk hipotesis ketiga $Y=82+0,43 X_{3}$, artinya bila iklim sekolah dikembangkan satu skala maka motivasi kerja guru MTsN Pasir Lawas akan bertambah sebesar 0,43 skala. Persamaan ini memberikan makna pada variabel iklim sekolah memberikan kontribusi signifikan terhadap motivasi kerja guru MTsN Pasir Lawas.

4. Untuk hipotesis keempat $\mathrm{Y}=$ $1,634+0,435 X_{1}+0,265 X_{2}+0,326$ $\mathrm{X}_{3}$, artinya bila kepemimpinan kepala sekolah, profesionalisasi guru dan iklim sekolah dikembangkan satu skala maka motivasi kerja guru MTsN Pasir Lawas akan bertambah sebesar 0,435 skala dari kepemimpinan kepala sekolah, 0,265 skala dari profesionalisasi guru dan 0,326 skala dari iklim sekolah.

Jika tidak dikembangkan secara bersamasama, maka motivasi kerja guru akan berkurang. motivasi kerja guru MTsN Pasir Lawas cenderung menurun bila kepemimpinan kepala sekolah, profesionalisai guru dan iklim sekolah tidak ditingkatkan oleh pengelola pendidikan baik guru itu sendiri maupun kepala sekolah, pengawas sekolah ataupun kepala Kementerian Agama Kabupaten Tanah Datar.

Gambaran antara variabel tidak menunjukkan benar-benar independen walaupun secara statistik independen. Hal ini ditunjukan dari korelasi ganda dan koefisien kerelasi parsial. Sebagaimana yang dikatakan Suharsimi Arukunto (1999:74) bahwa sikap atau prilaku seseorang dapat ditingkantkan melalui pembinaan yang didukung oleh hubungan interpersonal yang kondusif. Dengan demikian untuk meningkatkan motivasi kerja guru MTsN Pasir Lawas sebaiknya dilakukan peningkatan kepemimpinan kepala sekolah, profesionalisasi gur dan iklim sekolah secara bersama-sama dengan tidak melupakan peningkatan aspek lainnya yang belum diungkapkan dalam penelitian ini.

\section{PENUTUP}

Penelitian ini menemukan bahwa motifasi kerja guru pada dasarnya adalah relatif, artinya jika seorang guru dalam kepemimpinan kepela sekolah yang kurang baik, tidak melakukan profesionalisasi guru, dan iklim sekolah yang kurang kondusif, maka motifasi kerja guru cenderung rendah, dan begitu pula sebaliknya.

Temuan ini mengimplikasikan bahwa kepemimpinan kepala sekolah perlu dikembangkan ke arah yang lebih baik agar mampu melakukan perubahan, dan pembaharuan motivasi kerja guru dalam upaya meningkatkan mutu pendidikan, peningkatan kemampuan kepala sekolah dapat dilakukannya secara mandiri atau dengan bantuan orang lain, melalui peningkatan pendidikan pada strata yang lebih tinggi.

Kepala sekolah hendaknya memperbaiki pendekatan dan peningkatan proses profesionalisasi guru, sehingga dapat 
menumbuh kembangkan potensi diri guru guna meningkatkan motivasi kerjanya, profesionalisasi guru yang dilakukan sebaiknya adalah pembinaan yang dapat memacu perubahan pada guru, menumbuhkan semangat kerja guru, tanggung jawab dan komitmen terhadap tugas serta ingin selalu untuk berubah dan belajar.

Iklim sekolah sebaiknya diupayakan agar lebih kondusif oleh kepala sekolah dan guru. Semua penyelenggara pendidikan agar dapat berintegrasi dengan suasana keakraban, keterbukaan, perasaan empati, dan rasa kebersamaan. Melalui hal demikian itu iklim sekolah dapat tercipta dengan baik, sehingga motivasi kerja guru dapat meningkat. Untuk meningkatkan iklim sekolah yang kondusif, diperlukan komitmen, kebersamaan dan mendahulukan kepentingan bersama dari kepentingan pribadi.

Temuan penelitian ini juga berimplikasi bahwa motivasi kerja guru perlu ditumbuh kembangkan melalui kepemimpinan yang berprinsip dan sikap keteladanan kepala sekolah, dengan motivasi kerja guru yang tinggi, guru dapat melaksanakan tugas dengan baik guna mencapai tujuan pendidikan. Motivasi kerja guru dapat ditingkatkan melalui peningkatan pemahaman dan pengetahuan tentang motivasi, menumbuhkembangkan motivasi kerja dengan memperkuat motif-motif instrinsik dan ekstrinsik.

\section{KEPUSTAKAAN ACUAN}

Saelan Hasri. 2002, Sekolah Efektif, Yayasan Pendidikan Makasar

Sahertian. 1990, Sepervisi Pendidikan Dalam Ragka Program Inservice Education, Jakarta: Bina Cipta.

Soetjipto. 1999, dkk., Profesi Keguruan. Jakarta: PT Rineka Cipta

Soewarjo. 2004, Kepala Sekolah dan Tanggung Jawabnya, Yogyakarta: Kanisius

Sugiono. 2006, Metode Penelitian Pendidikan. Bandung: Alpabeta

Suharsimi Arukunto. 1999, Prosedur penelitian, Yogyakarta: Rineka Cipta

Sujana. 1982, Metode Statistic, Bandung: Tarsito 